\title{
Konya İli Açık Tarla Koșullarında Marul Bitkisinin Su-Verim Parametrelerinin Belirlenmesi ${ }^{\star \star}$
}

\author{
Yildirim Fekrt Abdulrazzaq AL-BAYATI Mehmet ȘAHIN $\quad$ M * \\ 'Selçuk Üniversitesi, Ziraat Fakültesi, Tarımsal Yapılar ve Sulama Bölümü
}

*Sorumlu yazar e-mail (Corresponding author e-mail): mhsahin@selcuk.edu.tr Geliș tarihi (Received): 19.07.2018

Kabul tarihi (Accepted): 14.9.2018

DOI: $10.21657 /$ topraksu. 460725

Öz

Bu araștırma, Konya ili açık tarla șartlarında Cuore (Lactuva Sativa L. var. Iongifolia) marul çeșidinin su-verim fonksiyonlarını belirlemek amacıyla, Toprak Su ve Çölleșme ile Mücadele Araștırma Enstitüsü deneme arazisinde 2017-2018 yılı yetiștirme sezonunda yürütülmüștür. Çalıșmada 4 gün sulama aralığında dört farklı sulama düzeyi uygulanmıștır. Sulama düzeyleri, A sınıfı buharlașma kabından

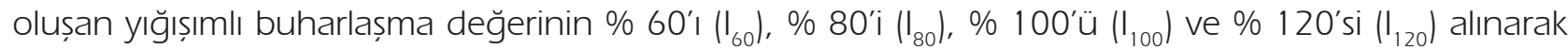
olușturulmuștur. Deneme tesadüf blokları deneme deseninde üç tekerrürlü olarak yürütülmüștür.

Araștırma sonuçlarına göre, mevsimlik su tüketimi en yüksek 441.9 mm ile $I_{120}$ konusunda, en düșük 317.8 mm ile I ${ }_{60}$ konusunda gerçekleșmiștir. En yüksek ortalama pazarlanabilir baș ağırlığı 865.85 g ile $\mathrm{I}_{120}$ konusunda, en düșük ortalama pazarlanabilir baș ağırlığı ise $475.68 \mathrm{~g}$ ile $\mathrm{I}_{60}$ konusunda bulunmuștur. Sulama suyu ve su kullanım randımanları, konulara bağlı olarak, sırasıyla 14.6-18.3 $\mathrm{kg} \mathrm{m}^{-3}$ ve $12.5-$ $17.0 \mathrm{~kg} \mathrm{~m}^{-3}$ arasında değișmiștir. Marul verim tepki etmeni (ky) ise 1.38 olarak bulunmuștur. A sınıfı buharlașma kabından meydana gelen buharlașma değerinin \% 100'ünün sulama suyu olarak verildiği konu ideal sulama programı olarak önerilmiștir.

Anahtar Kelimeler: A sınıfı buharlașma kabı, damla sulama yöntemi, konya, marul bitkisi, verim tepki etmeni

${ }^{*}$ Yüksek Lisans tezinden türetilmiștir.

\section{Determination of Water-Yield Parameters of Lettuce Plant in Konya Open Field Conditions}

\section{Abstract}

This research was conducted to determine water-yield functions of Cuore (Lactuva Sativa L. var. Longifolia) lettuce cultivars under open field conditions at research station of Konya Soil, Water and Deserting Control Research Institute during 2017-2018 growing season. In the study, four different irrigation treatments were constituted as $60 \%\left(I_{60}\right), 80 \%\left(I_{80}\right), 100 \%\left(I_{100}\right)$ and $120 \%\left(I_{120}\right)$ of the cumilative evaporation measured from the Class A Pan within 4 days period. The experiment was conducted according to randomized block design with three replications.

According to research results, maximum evaportanspration rate was measured in $I_{120}$ treatment as $441.9 \mathrm{~mm}$ while minimum evapotranspiration was measured in $\mathrm{I}_{60}$ treatment as $317.8 \mathrm{~mm}$. The highest average marketable head weight was obtained at $\mathrm{I}_{120}$ treatment with $865.85 \mathrm{~g}$ and the lowest average marketable head weight was obtained at $\mathrm{I}_{60}$ treatment with $475.68 \mathrm{~g}$. Irrigation water use efficiency and 
water use efficiency varied between $14.6-18.3 \mathrm{~kg} \mathrm{~m}^{-3}$ and $12.5-17.0 \mathrm{~kg} \mathrm{~m}^{-3}$, respectively, depending on the treatments. The yield response factor (ky) was found as $1.38100 \%$ of the cumilative evaporation of the Class A Pan is recommended as a optimal irrigation program for drip irrigated lettuce crop under field condition to get higher and quality lettuce yield for the Konya Region.

Key words: class A pan, drip irrigation method, konya, lettuce plant, yield response factor

\section{Giriș}

Konya ili, kurak ve yarı kurak bir iklim özelliğine sahiptir. Dolayısıyla su bölgede bitkisel üretim için hayati bir öneme sahiptir. Bir bölgenin su kaynakları potansiyeli, bitki desenini ve sulama programlamasını etkileyen en önemli unsurdur. Son yıllarda iklim değișikliği ve gelișen ülke koșulları dikkate alındığında çiftçilerin, birim alandan daha çok gelir elde etme istekleri sulu tarım arazilerinin giderek artmasına dolayısıyla mevcut su kaynakları üzerinde baskıya sebep olmaktadır. Bu durum, tarımsal sulamanın önemini daha da arttırmakta ve su kaynaklarının daha da etkin kullanılmasını gündeme getirmektedir. Kısıtlı su kaynaklarının üzerinde, sanayi ve kentsel su intiyacı baskısının artması sulamada kullanılan su potansiyelinin azalmasına ya da kalitesi düșük suların da tarımda kullanımasına neden olmaktadır (Özbahçe ve Tarı, 2010). Yeraltı ve yerüstü su kaynaklarından en iyi șekilde faydalanmak için, toprak-bitki- iklim ilișkileri çerçevesinde sulama zamanı ve miktarı arasındaki ilișkinin belirlenmesi gerekir (James, 1988). Sulama-verim ilișkileri, öncelikle sulama zamanı, uygulama yöntemi, su kalitesi, bitki, toprak heterojenliği ve iklimsel koșullar gibi faktörlere bağlıdır (Doorenbos, 1977).

Marul, dünya üzerinde üretimi yaygın olarak yapılan ve ekonomik değeri yüksek olan bir sebze çeșididir. Marul salata gurubu sebzeler içerisinde en çok tüketilen ve yılın tamamında pazarda bulunabilen tek senelik serin iklim sebzesidir (Stagnari et al., 2015). FAO'nun 2016 verilerine göre dünyada marul türleri 1.223 .407 ha alanda üretilmekte ve 26.779 .564 ton verim elde edilmektedir (FAOSTAT, 2018). Türkiye İstatistik Kurumu verilerine göre 2016 yılında, Türkiye genelinde toplam marul türleri üretimi; 221.516 da alanda 478.442 ton, Konya ilinde ise toplam 1143 da alanda 3207 ton olarak gerçekleșmiștir (TUIK, 2016).

Marul ile ilgili araștırmalar genellikle sera koșularında; bitki besleme, gübreleme, bitki koruma ve az da olsa sulama konularında yapılmıștır. Öneș vd. (1995), Yazgan vd. (2006), Acar vd. (2008), Kuslu vd. (2008), Bozkurt vd. (2009), Senyigit ve Kaplan (2013) ve Yıldırım vd. (2015) yaptıkları araștırmalarda farklı A sınıfı buharlașma kap katsayıları kullanarak seralarda marul bitkisi için sulama programları olușturmușlardır. Ancak açık tarla koșullarında sulama konusunda yapılımıș araștırma sayısı azdır. Bu araștırma, Konya ilinde açık tarla koșullarında, sulama programı A sınıfı buharlașma kabına göre yapılan ve damla sulama yöntemi ile sulanan marul bitkisinin su-verim fonksiyonlarının belirlenmesi amacıyla yürütülmüștür.

\section{MATERYAL VE YÖNTEM}

Araștırma, Konya Toprak Su ve Çölleșme ile Mücadele Araștırma Enstitüsü deneme arazisinde yürütülmüștür. Deneme alanının koordinatları ve Google Earth görüntüsü Șekil I'de verilmiștir.

Araștırmada, Yedikule (Lactuva Sativa L. var. longifolia) Cuore marul çeșidi kullanıımıștır.

Konya ili, Türkiye'nin en az yağıș alan bölgelerinden bir tanesidir. Araștırmanın yürütüldüğü yıla ait bazı iklimsel parametreler Çizelge 1'de verilmiștir (DMi 2017). Bölgede yağıș miktarları buharlașma miktarlarına oranla çok düșüktür. Dolayısıyla bölgede tarımsal faaliyetler için sulama mutlak suretle gereklidir.

Araștırma alanı topraklarından 0-30 ve 30-60 $\mathrm{cm}$ derinlikten alınan örneklerde yapılan analiz sonuçlarına göre; her iki katmanda da bünye killi olup, hacim ağırlığı değerleri sırası ile 1.32-1.33

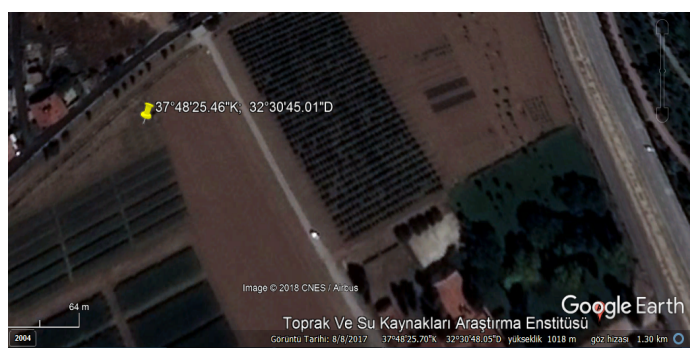

Șekil 1. Deneme alanının görüntüsü

Figure 1. Experimental area 
Çizelge 1. Konya iline ait bazı iklim verileri

Table 1. Meteorological data of Konya province

\begin{tabular}{|c|c|c|c|c|c|c|}
\hline Yıllar & İklim elemanları & Mayıs & Haziran & Temmuz & Ağustos & Eylül \\
\hline \multirow{5}{*}{2017} & Ortalama sıcaklık (C) * & 15.2 & 20.2 & 24.6 & 23.6 & 20.7 \\
\hline & Ortalama bağıl nem (\%) & 57.7 & 55 & 35.6 & 45.2 & 31.2 \\
\hline & Toplam yağıș (mm) * & 33,7 & 5.2 & - & 7.2 & - \\
\hline & Ort. rüzgar hızı $\left(\mathrm{m} \mathrm{s}^{-1}\right)^{*}$ & 1,2 & 1.1 & 1.1 & 1.1 & 0.5 \\
\hline & Toplam buharlașma (mm) & 130.2 & 162 & 269.7 & 229.4 & 171 \\
\hline \multirow{5}{*}{$\begin{array}{c}\text { Uzun yıllar } \\
\text { ortalaması } \\
\text { (1960-2016) }\end{array}$} & Ortalama sıcaklık & 15.7 & 20.1 & 23.4 & 22.8 & 18.4 \\
\hline & Ortalama bağıl nem (\%) & 55.9 & 48.4 & 42.1 & 42.9 & 48.0 \\
\hline & Toplam yağıș (mm) & 44.3 & 23.9 & 6.5 & 5.4 & 12.9 \\
\hline & Ort. rüzgar hızı $\left(\mathrm{m} \mathrm{s}^{-1}\right)$ & 2.2 & 2.5 & 2.8 & 2.6 & 2.1 \\
\hline & Toplam buharlașma (mm) & 155.0 & 210.5 & 269.0 & 250.1 & 172.1 \\
\hline
\end{tabular}

* Araștırma alanında bulunan meteoroloji istasyonundan alınan değerler

$\mathrm{g} \mathrm{cm}^{-3}$ dür. Toprağın faydalı su kapasitesi (0-30 $\mathrm{cm})$ iccin $36.09 \mathrm{~mm},(30-60 \mathrm{~cm})$ için ise $31.05 \mathrm{~mm}$ olarak hesaplanmıștır. Toprakların $\mathrm{pH}$ değerleri 8.06 ve 7.93 , tuzluluk değerleri ise 0.57 ve 0.73 dS m olarak belirlenmiștir. Araștırmada kullanılan sulama suyu $C_{2} S_{1}$ sinifindadir.

Araștırmada, A sınıfı buharlașma kabından 4 günde olușan buharlașmanın farklı pan katsayıları ile hesaplanması sonucu bulunan 4 farklı sulama konusu (\% 60' ו ( $\left(_{60}\right)$, \% 80'i $\left(I_{80}\right), \%$ 100'ü $\left(I_{100}\right)$ ve \% 120'si $\left.\left(I_{120}\right)\right)$ denenmiștir. Araștırma tesadüf blokları deneme desenine göre 3 tekerrürlü olarak yürütülmüștür. Her parsele sıra arası $0.40 \mathrm{~m}$ sıra üzeri $0.30 \mathrm{~m}$ olacak șekilde marul fide dikimi yapılmıștır. Her parselde 4 sıra marul olacak șekilde parsel eni $1.6 \mathrm{~m}$, parsel boyu ise $3 \mathrm{~m}$ olarak belirlenmiștir. Bloklar arasında $2 \mathrm{~m}$, parseller arasında ise $1.2 \mathrm{~m}$. mesafe bırakılmıștır.

Marul bitkisinin sulanmasında damla sulama yöntemi kullanılmıștır. Sistemde; çapı 16 mm, lateral aralığı $40 \mathrm{~cm}$, damlatıc aralığı $30 \mathrm{~cm}$ damla sulama borusu kullanılmıș ve 1 atm basınçta damlatıcı debisi $4 \mathrm{~L} \mathrm{~h}^{-1}$ olarak belirlenmiștir.

Dikim öncesi denemenin yürütüleceği alana dekara 20 kg DAP gübresi uygulaması yapılmıștır. Marul fidelerinin dikimi 13 Temmuz 2017 tarihinde el ile doğrudan parsellere yapılmıștır. Deneme boyunca herhangi bir ilaca intiyaç duyulmamıștır. Hasat 5 Eylül 2017 tarihinde el ile yapılmıștır. Bütün deneme parsellerinde, her bir parselin orta iki sırasından 10'ar adet marul bitkisi hasat edilerek verim ve verim parametreleri incelenmiștir.
Dikim sonrası çimlenme ve homojen çıkıș için sulama yapılmıștır. Daha sonra toprağın $0-60 \mathrm{~cm}$ lik mevcut nemi tarla kapasitesine getirilmiștir. Sulama konularına, faydalı su kapasitesinin yaklașık \% 30'u tüketildiğinde (Kırda vd., 2005; Öktem 2006) bașlanmıștır. Sulama suyu miktarları Eșitlik 1 yardımı ile hesaplanmıștır. Uygulanan sulama suyu miktarları parsellere yerleștirilen su sayaçları ile kontrol edilmiștir.

$$
\mathrm{I}=\mathrm{A} \times \mathrm{Epan} \times \mathrm{Kpc}
$$

Eșitlikte; I parsellere uygulanan sulama suyu miktarı (litre), Epan 4 gün sulama aralığında A sınıfı kaptan olușan buharlașmaların toplamı (mm), Kpc deneme konusuna ilișkin pan katsayısıdır

Bitki su tüketimi, gravimetrik yöntem ile 0-60 cm derinliğinde ölçülen toprak nem değerleri dikkate alınarak Eșitlik 2'ye göre hesaplanmıștır (James, 1988).

$$
E T=I+R-D p+C p-R f+\Delta S
$$

Eșitlikte; ET: Bitki su tüketimi (mm), I: Sulama suyu miktarı (mm), R: Etkili yağıș (mm), Dp: Kök bölgesi altına derine sızma kayıpları (mm), Cp: Kök bölgesi altından kapilar yükselme $(\mathrm{mm})$, Rf: Yüzey akıș kayıpları (mm), $\Delta \mathrm{S}$; Toprak profilindeki su içeriği değișimi $(\mathrm{mm})$ dir. Dp değeri, sulama öncesi ve sonrası 60 ve $90 \mathrm{~cm}$ derinliklerde gravimetrik metodla hesaplanmıștır. CP ve Rf değerleri ise deneme alanının drenaj bakımından sorunsuz olması ve sulama yönteminin uygun planlanması sonucu dikkate alınmamıștır. $\Delta S$, marul ekimi öncesi ve hasattaki toprak nem ölçümleri arasındaki farktan hesaplanmıștır. 
Sulama programlarının değerlendirilmesinde kullanılan su ve sulama suyu kullanım randıman değerleri Eșitlik 3 ve 4 yardımı ile hesaplanmıștır (Howell ve ark, (1990). Hesaplamalarda dekardan elde edilen pazarlanabilir baș ağırlığı değerleri kullanılmıștır.

$$
\begin{aligned}
& W U E=\frac{E_{y}}{E T} \\
& \text { WUE }=\frac{E_{y}}{l}
\end{aligned}
$$

Eșitlikte; WUE: Su kullanma randımanı (Kg $\left.\mathrm{da}^{-1} \mathrm{~mm}^{-1}\right), \quad E y=$ Ekonomik verim $\left(\mathrm{Kg} \mathrm{da}^{-1}\right) \mathrm{ET}=$ Mevsimlik bitki su tüketimi (mm), IWUE= Sulama suyu kullanma randımanı $\left(\mathrm{Kg} \mathrm{da}^{-1} \mathrm{~mm}^{-1}\right)$ I= Sulama suyu miktarı (mm).

Bitkilerin su-verim ilișkilerini belirlemek için birçok model geliștirilmiștir. Bunlar içerisinde Stewart eșitliği en yaygın kullanılan modellerden birisidir (Stewart ve ark, 1976; Doorenbos ve Kassam, 1979). Bu model oransal bitki su tüketimi eksikliği ile oransal verim azalıșı arasındaki ilișkiye dayanmakta olup, verim tepki etmeni hesaplanmaktadır. Birden büyük ky değerleri, bitkinin su kısıtına hassas olduğunu, birden küçük ky değerleri ise bitkinin su kısıtına toleranslı olduğunu göstermektedir (Steduto ve ark, 2012). Modele ait eșitlik așağıda verilmiștir (Eșitlik 5).

$(1-Y a / Y m a x)=k y(1-E T a / E T m a x)$

Bu eșitlikte; Ya: su kısıntısı koșullarında gerçek verim ( $\mathrm{kg} \mathrm{da-1}), Y \mathrm{~m}$ : tam sulama koșulunda en yüksek verim ( $\left.\mathrm{kg} \mathrm{da}^{-1}\right)$, ETa: su kısıntısı koșullarında gerçek bitki su tüketimi (mm), ETm: tam sulama koșulunda en yüksek bitki su tüketimi $(\mathrm{mm})$ ve ky: su-verim tepki etmenini göstermektedir.
Verim ve verim parametreleri arasındaki farklııkları belirlemek için varyans analizi yapılmıș ve sonuçlar \% 1 ve \% 5 önem düzeyine göre Duncan testi esas alınarak gruplandırımıștır. Yurtsever (1984); Düzgüneș vd. (1987). İstatiksel analizler "SPSS1 1.0" bilgisayar paket programı kullanılarak gerçekleștirilmiștir.

\section{BULGULAR VE TARTIȘMA}

\section{Uygulanan Sulama Suyu ve Bitki Su Tüketim Değerleri}

Sulama tarihleri ile uygulanan sulama suyu miktarları Çizelge 2 de verilmiștir. Marul bitkisinin

Çizelge 2. Verilen sulama suyu miktarları (mm) Table 2. Applied irrigation water amounts $(\mathrm{mm})$

\begin{tabular}{cllll}
\hline \multirow{2}{*}{ sulama tarihleri } & \multicolumn{4}{c}{ Deneme Konuları } \\
\cline { 2 - 5 } & \multicolumn{1}{c}{$\mathrm{I}_{60}$} & \multicolumn{1}{c}{$\mathrm{I}_{80}$} & \multicolumn{1}{c}{$\mathrm{I}_{100}$} & \multicolumn{1}{c}{$\mathrm{I}_{120}$} \\
\hline 13-27 Temmuz & 120 & 120 & 120 & 120 \\
01 Ağustos & 12 & 16 & 20 & 24 \\
05 Ağustos & 15 & 20 & 25 & 30 \\
09 Ağustos & 21.6 & 28.8 & 36 & 43.2 \\
13 Ağustos & 28.8 & 38.4 & 48 & 57.6 \\
17 Ağustos & 21.6 & 28.8 & 36 & 43.2 \\
21 Ağustos & 18 & 24 & 30 & 36 \\
25 Ağustos & 12 & 16 & 20 & 24 \\
30 Ağustos & 21.6 & 28.8 & 36 & 43.2 \\
\hline Toplam & $\mathbf{2 7 0 . 6}$ & $\mathbf{3 2 0 . 8}$ & $\mathbf{3 7 1}$ & $\mathbf{4 2 1 . 2}$ \\
\hline
\end{tabular}

vegetasyon süresi 54 gün olarak gerçekleșmiștir. Homojen bir çimlenme ve çııı i için 13-27 Temmuz tarihleri arasında toplam 120 mm su uygulanmıștır. Konulara ise 1 Ağustos'da bașlanmıș, 5 Eylül'de son verilmiștir. Denemeye bașlandıktan sonra, 4 gün sulama aralığında toplam 8 kez sulama yapılmıștır.

Araștırmada uygulanan toplam sulama suyu

Çizelge 3. Farklı sulama düzeylerinde marul bitkisinin bitki su tüketim değerleri

Table 3. Evapotranspiration values of lettuce plants at different irrigation water levels

\begin{tabular}{ccccccc}
\hline Yıl & $\begin{array}{c}\text { Denmek } \\
\text { onuları }\end{array}$ & $\begin{array}{c}\text { Net sulama } \\
\text { suyu mitarları } \\
(\mathrm{mm})\end{array}$ & $\begin{array}{c}\text { Etkili yağıș } \\
(\mathrm{mm})\end{array}$ & $\begin{array}{c}\text { Ekimde } \\
\text { toprak nemi } \\
(\mathrm{mm} / 60 \mathrm{~cm})\end{array}$ & $\begin{array}{c}\text { Hasatta toprak } \\
\text { nemi } \\
(\mathrm{mm} / 60 \mathrm{~cm})\end{array}$ & $\begin{array}{c}\text { Mevsimlik bitki su } \\
\text { tük. (mm) }\end{array}$ \\
\hline \multirow{2}{*}{2017} & 270.6 & 7.2 & 168 & 128.0 & 317.8 \\
\cline { 2 - 7 } & $\mathrm{I}_{60}$ & 720.8 & 7.2 & 168 & 131.8 & 364.2 \\
\cline { 2 - 7 } & $\mathrm{I}_{80}$ & 371.0 & 7.2 & 168 & 145.6 & 400.6 \\
\hline $\mathrm{I}_{120}$ & 421.2 & 7.2 & 168 & 154.5 & 441.9 \\
\hline
\end{tabular}


miktarı konulara göre 270.6 ile $421.2 \mathrm{~mm}$ arasında değișmiștir. Marul bitkisinin vegetasyon süresi boyunca hesaplanan bitki su tüketimi $I_{60}, I_{80}$ $I_{100}$ ve $I_{120}$ deneme konularında sırasılyla, 317.8, 364.2, 400.6 ve $441.9 \mathrm{~mm}$ olarak hesaplanmıștır (Çizelge 3).

En yüksek marul su tüketimi 441.9 mm ile $I_{120}$, en az marul su tüketimi ise $317.8 \mathrm{~mm}$ ile $\mathrm{I}_{60}$ konusunda gerçekleșmiștir. Araștırmacılar yetișme sezonu boyunca marul bitkisinin su tüketim değerlerinin 100-400 mm arasında olușabileceğini bildirmișlerdir (Sammis et al.,1988; Gallardo vd., 1996; Karam vd., 2002; Kırnak vd., 2002; Kadayıfçı vd., 2004). Santosh ve ark (2017) ise yapmıș oldukları bir araștırmada marul bitkisinin toplam su intiyacını konulara göre 219 ile 339 mm arasında değiștiğini bildirmișlerdir.

\section{Verim ve Verim Unsurlarına İlișkin Sonuçlar}

Araștırma sonunda her parseldeki bitkiler kökleri ile birlikte hasat edilmișlerdir. Kökler su ile dikkatlice yıkanıp temizlenip kök ölçümleri yapıldıktan sonra kökler kesilerek baș tartımları yapıımıștır. Araștırma sonucunda, konulardan elde edilen ortalama baș ağırlıkları, pazarlanabilir baș ağırlıkları, ana kök uzunlukları, kök genișliği, baș boyları ve baș çaplarının ölçüm değerleri Çizelge 4'de verilmiștir

Açık tarla koșullarında yürütülen bu denemede en yüksek ortalama baș ağırlığı 934.82 g bitki ile $I_{120}$ konusundan, en düșük ortalama baș ağırlığı ise $530.89 \mathrm{~g} \mathrm{bitki}^{-1}$ ile $\mathrm{I}_{60}$ konusundan elde edilmiștir. Varyans analiz sonuçlarına göre konular arasında \% 1 önem seviyesinde farklılık bulunmuștur. Test sonuçlarına göre üç farklı verim grubu olușmuștur. $I_{100}$ ile $I_{120}$ konuları ilk grupta (a) yer alırken, $I_{80}$ konusu ikinci grupta (b) ve $I_{60}$ konusu ise üçüncü grupta (c) yer almıștır. Bozkurt vd. (2009), 2003 Kasım-2004 Șubat tarihleri arasında Türkiye'nin Doğu Akdeniz bölgesinde yapmıș oldukları bir çalıșmada; en yüksek verimin $\mathrm{KcP}_{125}$ konusundan $570 \mathrm{~g} \mathrm{bitki}^{-1}$, en düșük verimin ise $250 \mathrm{~g} \mathrm{bitki}^{-1} \quad \mathrm{Kcp}$ konusundan elde edildiğini belirtmișlerdir. Yıldırım vd. (2015) tarafından 2011-2012 yıllarında cam serada, farklı sulama konularının kıvırcık marulun verimine etkilerini belirlemek için yaptıkları çalıșmada da benzer sonuçlar bulunmuștur.

Denemede en yüksek ortalama pazarlanabilir baș ağırlığı $865.85 \mathrm{~g} \mathrm{bitki}^{-1}$ ile $\mathrm{I}_{120}$ konusundan, en düșük ortalama baș ağırlığı ise $475.68 \mathrm{~g} \mathrm{bitki-1}^{-1}$ ile $I_{60}$ konusundan elde edilmiștir. Varyans analiz sonuçlarına göre konular arasında \% 1 önem seviyesinde farklılık bulunmuștur. Duncan testi sonuçlarına göre üç farklı verim grubu olușmuș $I_{120}$ ve $I_{100}$ konuları ilk grupta (a), $I_{80}$ konusu ikinci grupta (b) ve I ${ }_{60}$ konusu ise üçüncü grupta (c) yer almıștır. Karam vd. (2002) ile Acar vd. (2008), yapmıș oldukları araștırmalarda uygulanan sulama suyu artıkça marul baș ağırlıklarının artığını belirtmișlerdir. Kırnak vd. (2016), AralıkȘubat aylarında Șanlıurfa'da ısıtımayan serada farklı sulama düzeylerinin marul verimine etkisini inceledikleri çalıșmada; en yüksek ortalama marul verimini tam suluma yaptıkları $\mathrm{Kp}$, konusundan $\left(I_{100}\right) 7.8$ ton dekar' ${ }^{-1}$ olarak belirlemișlerdir.

Ortalama pazarlanabilir baș ağırlığı- net sulama suyu ve bitki su tüketimi miktarları arasında doğrusal ilișkiler olduğu görülmektedir (Șekil 2). Marul veriminin su kullanımına olan doğrusal ilișkisi önceki çalıșmalarla da uyumludur (Sammiset al., 1988; Gallardo vd., 1996; Kırnak vd., 2002).

En yüksek ortalama ana kök uzunluğu 15.88 $\mathrm{cm}$ ile $I_{100}$ konusunda ve en düșük ortalama ana kök uzunluğu ise $15.23 \mathrm{~cm}$ ile ${ }_{120}$ konusundan elde edilmiștir. En yüksek ortalama kök genișliği 21.50 $\mathrm{cm}$ ile $I_{100}$ konusundan, en düșük ortalama kök

Çizelge 4. Sulama uygulamalarının marulların ortalama verim öğeleri üzerindeki etkileri

Table 4. The effects of irrigation water application on mean lettuce yield components

\begin{tabular}{|c|c|c|c|c|c|c|}
\hline $\begin{array}{l}\text { Sulama } \\
\text { Seviyeleri }\end{array}$ & $\begin{array}{c}\text { Baș Ağırlığı } \\
\text { (g bitki-1) }\end{array}$ & $\begin{array}{l}\text { Pazarlanabilir } \\
\text { Baș Ağırlığı } \\
\text { (g bitki-1) }\end{array}$ & $\begin{array}{l}\text { Ana Kök } \\
\text { Uzunluğu } \\
\text { (cm) }\end{array}$ & $\begin{array}{l}\text { Kök genișliği } \\
\text { (cm) }\end{array}$ & $\begin{array}{l}\text { Baș Boyu } \\
(\mathrm{cm})\end{array}$ & $\begin{array}{c}\text { Baș Çapı } \\
\text { (cm) }\end{array}$ \\
\hline$I_{60}$ & $530.89 c$ & $475.68 c$ & 15.83 & 18.29 & $24.66 c$ & $21.08 c$ \\
\hline $\mathrm{I}_{80}$ & $710.64 b$ & $647.04 \mathrm{~b}$ & 15.32 & 20.28 & $27.60 \mathrm{~b}$ & $24.92 \mathrm{~b}$ \\
\hline$I_{100}$ & $877.12 a$ & 816.79a & 15.88 & 21.50 & 29.69a & 27.17ab \\
\hline$I_{120}$ & 934.82 a & 865.85a & 15.23 & 21.29 & $30.72 a$ & $27.92 a$ \\
\hline
\end{tabular}




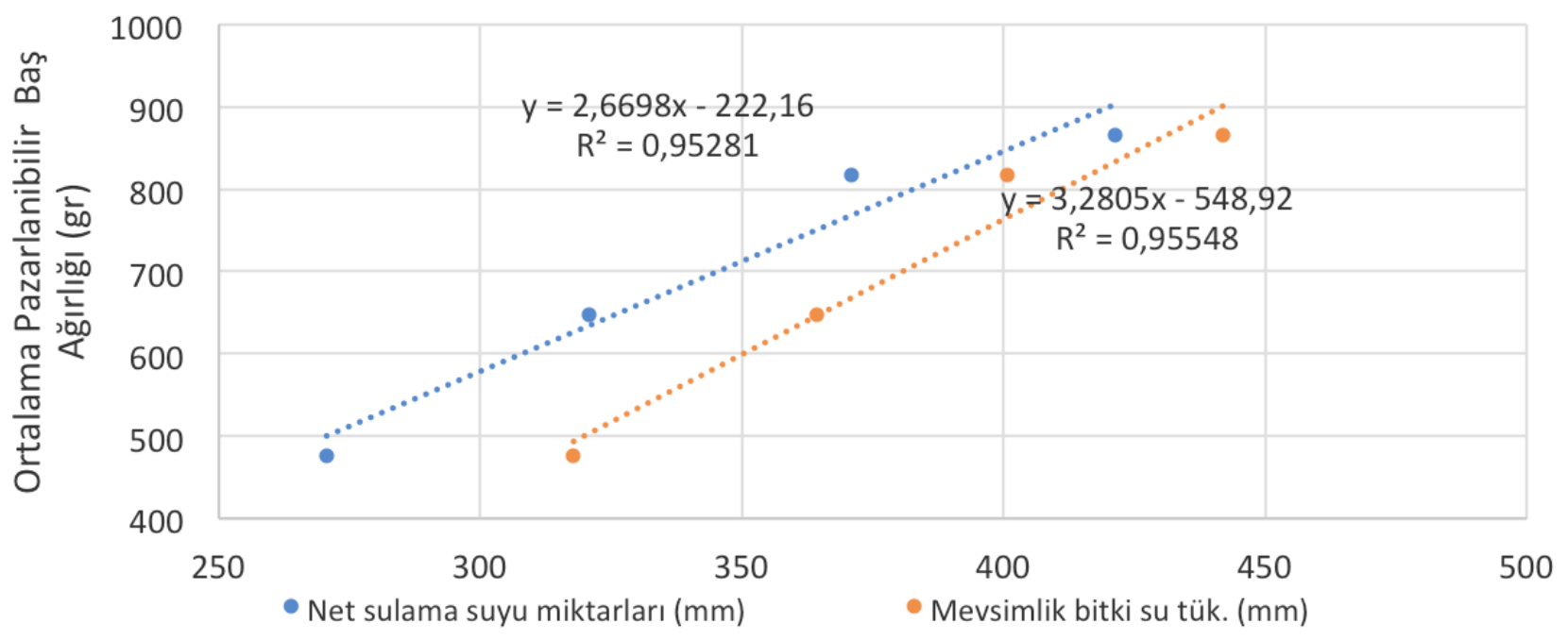

Șekil 2. Ortalama pazarlanabilir baș ağırlığı-uygulanan net sulama suyu ve bitki su tüketim ilișkileri

Figure 2. The relationships between evapotranspiration - mean lettuce marketable head and applied net irrigation water

genișliği 18.29 cm ile I ${ }_{60}$ konusundan ölçülmüștür (Çizegele 4). Varyans analiz sonuçlarına göre konular arasında ortalama ana kök uzunluğuna ve genișliğine ilișkin istatiksel açıdan farklılık bulunmamıștır. Acar vd. (2008) farklı su ve azot seviyelerinin marul verimi ve verim parametrelerine etkisini inceledikleri çalıșmalarında; ortalama kök uzunluklarının artan su miktarlarıyla önemli ölçüde değișmediğini belirtmișlerdir.

En yüksek ortalama baș boyu $30.72 \mathrm{~cm}$ ile $I_{120}$ konusundan, en düșük ortalama baș boyu 24.66 cm ile I ${ }_{60}$ konusundan ölçülmüștür (Çizegele 4). Bu değer $I_{100}$ konusunda $29.69 \mathrm{~cm}, \mathrm{I}_{80}$ konusunda ise $27.60 \mathrm{~cm}$ olarak belirlenmiștir. Varyans analiz sonuçlarına göre konular arasında \% 1 önem seviyesinde farkllık bulunmuștur. Konular arasında üç farklı grup olușmuș I ${ }_{120}$ ve I ${ }_{100}$ konuları ilk grupta (a) yer alırken, $I_{80}$ konusu ikinci grupta (b) ve I ${ }_{60}$ konusu ise üçüncügrupta (c) yer almıștır. Kuslu vd. (2008), yapmıș oldukları bir araștırmada; baș uzunluğunun sulama suyu miktarı ile birlikte arttığını vurgulamıșlardır. Benzer bir sonuçda, Kırnak vd. (2002) tarafindan farklı sulama düzeylerinin marul bitkisi verim ve parametreleri üzerine etkisini belirlemek üzere yaptıkları çalıșmada ortaya çıkmıștır. Uygulanan sulama suyu miktarının artması sonucu baș boyunun da arttığını bildirmișlerdir.

En yüksek ortalama baș çapı $27.92 \mathrm{~cm}$ ile $I_{120}$ konusunda, en düșük ortalama baș çapı ise 21.08 $\mathrm{cm}$ ile $\mathrm{I}_{60}$ konusundan elde edilmiștir. Bu değer $\mathrm{I}_{100}$ konusunda $27.17 \mathrm{~cm}, I_{80}$ konusunda ise $24.92 \mathrm{~cm}$ olarak belirlenmiștir. Varyans analiz sonuçlarına göre konular arasında \% 1 önem seviyesinde farklılık bulunmuștur. Konular arasında üç farklı grup olușmuș, $I_{120}$ konusu ve $I_{100}$ konusu ilk grupta, $I_{100}$ ve I $_{80}$ konusu ikinci grupta yer alırken, $\mathrm{I}_{60}$ konusu ise üçüncü grupta yer almıștır. Benzer sonuçlar; Kuslu vd. (2008) ile Kırnak vd. (2002) tarafından yapılan çalıșmalarda da bulunmuștur. Uygulanan sulama suyu miktarının artması sonucu baș çapının da artığını bildirmișlerdir.

Çizelge 5. Sulama suyu ve su kullanım randımanı

Table 5. Irrigation water and water use efficiency

\begin{tabular}{|c|c|c|c|c|c|}
\hline Konular & $\begin{array}{l}\text { Sulama Suyu } \\
(\mathrm{mm})\end{array}$ & $\begin{array}{l}\text { Bitki su tük. } \\
\text { (mm) }\end{array}$ & $\begin{array}{l}\text { Pazarlanabilir } \\
\text { Baș ağırlığı } \\
\left(\mathrm{kg} \mathrm{da}^{-1}\right)\end{array}$ & $\begin{array}{l}\text { IWUE } \\
\left(\mathrm{kg} \mathrm{m}^{-3}\right)\end{array}$ & $\begin{array}{c}\text { WUE } \\
\left(\mathrm{kg} \mathrm{m}^{-3}\right)\end{array}$ \\
\hline $\mathrm{I}_{60}$ & 270.6 & 317.8 & 3963.8 & 14.6 & 12.5 \\
\hline$I_{80}$ & 320.8 & 364.2 & 5391.7 & 16.8 & 14.8 \\
\hline$I_{100}$ & 371.0 & 400.6 & 6806.3 & 18.3 & 17.0 \\
\hline$I_{120}$ & 421.2 & 450.8 & 7215.1 & 17.1 & 16.0 \\
\hline
\end{tabular}




\section{Sulama suyu ve su kullanım randımanı}

Ortalama pazarlanabilir baș ağırlıklarının uygulanan sulama suyu miktarlarına bölünmesiyle sulama suyu kullanım randımanı (IWUEE); ortalama pazarlanabilir baș ağırlıklarının mevsimlik bitki su tüketim değerlerine bölünmesiyle ise su kullanım randımanı (WUE) hesaplanmıștır (Çizelge 5).

Çizelge 5 incelendiğinde; toplam su kullanım randımanı değerleri $12.5-17.0 \mathrm{~kg} \mathrm{~m}^{-3}$ arasında, sulama suyu kullanım randımanı değerleri ise 14.6 - $18.3 \mathrm{~kg} \mathrm{~m}^{-3}$ arasında değiștiği görülmektedir. En yüksek IWUE ve WUE değerleri sırasıyla 18.3 ve $17.0 \mathrm{~kg} \mathrm{~m}^{-3}$ ile $\mathrm{I}_{100}$ deneme konusundan elde edilirken, en düșük değerler ise $\mathrm{I}_{60}$ konusundan elde edilmiștir. Bozkurt vd. (2009) yaptıkları benzer bir çalıșma sonucu; konulara göre su kullanım randıman değerlerinin (WUE) 12.4$23.1 \mathrm{~kg} \mathrm{~m}^{-3}$; sulama suyu kullanım randımanı değerlerini ise (INWUE) ise; $13.7-28.2 \mathrm{~kg} \mathrm{~m}^{-3}$ arasında bulmușlardır. Kırnak vd. (2016), AralıkȘubat aylarında Șanlıurfa'da ısııılmayan serada farklı sulama düzeylerinin marul verimine etkisini inceledikleri çalıșmada; maksimum sulama suyu kullanımı ve toplam su kullanım etkinliğini sırasıyla 0.117 ve 0.074 ton $\mathrm{da}^{-1} \mathrm{~mm}^{-1}$ ile elde etmișlerdir.

\section{Verim Tepki Etmeni}

Marul bitkisinin verim tepki etmeninin belirlenmesi için oransal bitki su tüketim değerleri ile oransal verim azalıșları arasındaki ilișkiler
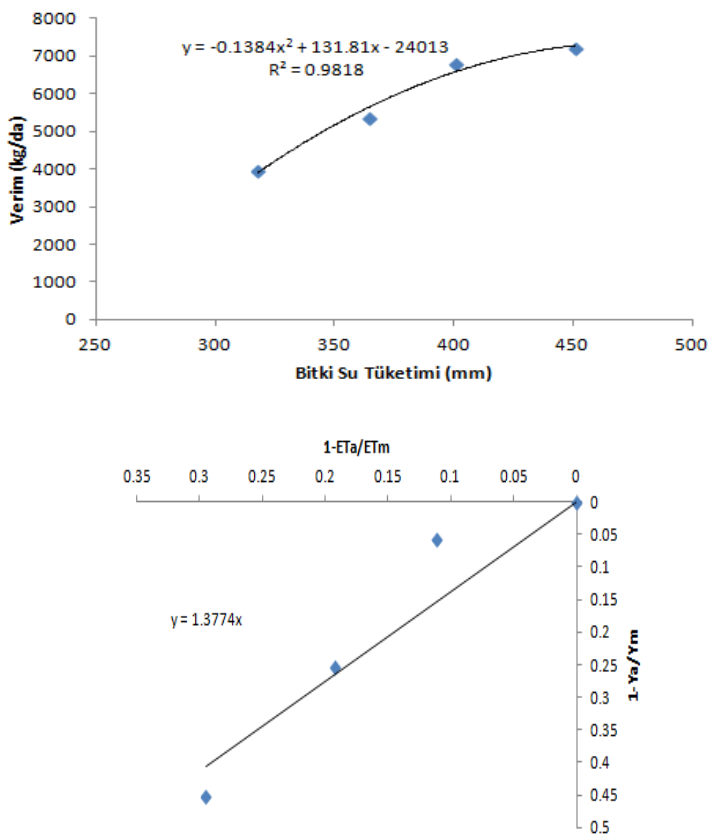

Șekil 3. Marul bitkisi ET-verim ilișkisi ve verim tepki etmeni

Figure 3. ET - yield relationship and yield response factor belirlenmiștir. Șekil 3'de marul bitkisinin ET-verim ilișkisi ve verim tepki etmeni grafiksel olarak gösterilmiștir.

Ky değerinin hesaplanmasında mevcut bitki su tüketim değerleri ve verim değerleri arasındaki ilișkiler, regresyon analizi yapılarak araștırılmıș ve bitki su tüketimi ile verim arasında polinomiyal bir ilișkinin bulunduğu belirlenmiștir. Araștırmadan elde edilen sonuçlara göre Marul verim tepki etmeni 1.38 olarak bulunmuștur. Bulunan verim tepki etmeni birden büyük olduğu için, açık tarla koșullarında yetiștirilen marulun su kısıtına hassas olduğu sonucuna varılabilir. Kuslu ve ark (2008) Erzurum'da açık tarla koșullarında yapmıș oldukları çalıșmada verim tepki etmenini 1.39 olarak hesaplamıșlardır. Kırnak vd., (2002); Kadayıfçı vd., (2004) sera koșullarında yürütülen bazı araștırmalarda marul verim etmeni birden küçük olarak hesaplanmıștır.

\section{SONUC}

Bu araștırma ile, Konya ili açık tarla koșullarında A sınıfı buharlașma kabı yöntemine göre belirlenen 4 farklı sulama konusunun, marul bitkisinin verim ve verim parametreleri üzerine etkisi incelenmiștir. Marul bitkisinin yetiștirme süresi en az su tüketimi $317.8 \mathrm{~mm}$ ile $\mathrm{I}_{60}$ konusunda, en fazla su tüketimi ise 441.9 mm olarak $I_{120}$ konusunda gerçekleșmiștir. En fazla sulama suyu $421.2 \mathrm{~mm} \mathrm{I_{120 }}$ ile en az sulama suyu $270.6 \mathrm{~mm}$ ile ise $\mathrm{I}_{60}$ konusuna uygulanmıștır. Tarımsal sulamalarda programlama yaparken dikkate alınan önemli kriterlerden su ve sulama suyu kullanım randımanlarının en yüksek değerleri sırasıyla 17.0 ve $18.3 \mathrm{~kg} \mathrm{~m}^{-3}$ ile $\mathrm{I}_{100}$ deneme konusundan elde edilirken, en düșük değerler ise yine sırsılla 12.5 ve $14.6 \mathrm{~kg} \mathrm{~m}^{-3}$ ile $\mathrm{I}_{60}$ konusundan elde edilmiștir. Konya koșullarında damla sulama yöntemi ile sulanan marul bitkisi için, 4 gün sulama aralığında, buharlașma kabından meydana gelen buharlașma miktarının tamamının sulama suyu olarak verildiği I ${ }_{100}$ sulama konusu (yaklașı $371 \mathrm{~mm}$ ) ideal sulama programı önerilmektedir.

\section{TEȘEKKÜR}

Bu yüksek lisans tez çalıșmasını araștırma projesi olarak destekleyen Selçuk Üniversitesi Bilimsel Araștırma Projeler Koordinatörlüğüne ve araștırmanın yürütülmesi için arazi tahsis eden Konya Toprak Su ve Çölleșme ile Mücadele Araștırma Enstitüsü'ne teșekkür ederiz. 


\section{KAYNAKLAR}

Acar B, Paksoy M, Türkmen Ö, Seymen M (2008). Irrigation and nitrogen level affect lettuce yield in greenhouse condition. African Journal of Biotechnology, 7 (24).

Bozkurt S, Mansuroğlu G, Kara M (2009). Responses of lettuce to irrigation levels and nitrogen forms, African Journal of Agricultural Research, 4 (11), 1171-1177.

\section{DMi (2015). Devlet Meteoroloji Müdürlüğü Kayıtları}

Doorenbos J, Pruitt WO (1992). Guidelines for predicting crop water requirement (3rd ed.) FAO irrigation and drainage paper, Rome. pp. 24-193.

Doorenbos J, Kassam A H (1979). Yield response to water. FAO Pub.33 Irrigation and Drainage Paper, Rome.

Düzgünes $O$, Kesici $T$, Kavuncu $O$, Gürbüz $F$ (1987). Araștırma Deneme Metodları (istatistik Metodları II). Ankara Üniversitesi Ziraat Fakültesi Yayınları, No. 1021, 214.

FAOSTAT (2018). Statistical database. http://mww.fao. org/faostat/en/\#data/OC

Gallardo M, Jackson L E, Schulbach K F, Snyder R L, Thompson R B, Wyland L J(1996). Production and water use in lettuces under variablewater supply, Irrig Sci 16, 125-137. doi:10.1007/ BF02215620.

Howell T A, Cuenca R H, Solomon K H, (1990). Crop yieldresponse. Manegement of farm irrigation systems, Edit. G.J. Hoffman., T.A. Howell., K.H. Solomon. Chap. 5. An ASAE Monograph, St. Joseph, MI pp. 93-116.

James L G (1988). Principles of farm irrigation systems design, John Wiley and Sons Limited

Kadayıfçı A, Tuylu G I, Uçar Y, Çakmak B, (2004). Effects of mulch and irrigation water amounts on lettuce's yield, evapotranspiration, transpiration and soil evaporation in Isparta location, Turkey. J Biol Sci 4, 751-755.

Karam F, Mounzer O, Sarkis F, Lahoud R (2002). Yield and nitrogen recovery of lettuce under different irrigation regimes, J. Appl. Hort, 4 (2), 70-76.

Kırda C, Topcu S, Kaman H, Ulger A, Yazici A, Cetin M Derici M (2005). Grain yield response and $\mathrm{N}$-fertiliser recovery of maize under deficit irrigation, Field Crops Research, 93 (2), 132-141.

Kırnak H, Demir S, Tas I, C Cakmaklı M (2002). Response of different irrigation water applications on yield and growth of lettuce grown in greenhouse, J Agric Fac Harran Uni, 6 (1-2), 47-54

Kırnak H, Taș I, Gökalp Z,Karaman S, (2016). Effects of different irrigation levels on yield of lettuce grown in an unheated greenhouse, Current Trends in Natural Sciences, 5 (9), 145-151.

Kuslu Y, Dursun A, Sahin U, Kiziloglu F M, Turan M (2008). Effect of deficit irrigation on curly lettuce grown under semiarid conditions, Spanish Journal of Agricultural Research, 6 (4), 714-719.

Öktem A (2006). Effect of different irrigation intervals to drip irrigated Dent Corn (Zea mays L. intendata) water-yield relationship. Pak. J. Biol. Sci. 9(8): 1476-1481.

Öneș A, Demir K, Çakmak B, Kendirli B (1995). Sera Koșullarında Yetiștirilen ve Damla Sulama Yöntemi Ile Sulanan Baș Salatanın Sulama Zamanının Planlanması. 5. Ulusal Kültürteknik K. Antalya: 207-219.

Özbahce A, TarıAF (2010). Effects of different emitterspace and water stress on yield and quality of processing tomato under semi-arid climate conditions. AgriculturalWater Management, Vol: 97(9): 1405-1410.

Santosh D T, Reddy R G, Tiwari K N (2017) Effect of Drip Irrigation Levels on Yield of Lettuce under Polyhouse and Open Field Condition International Journal of Current Microbiology and Applied Sciences ISSN: 231 9-7706 Volume 6 Number 7 pp. 1210-1220.

Sammis TW, Kratky B A, Wu I P, (1988). Effects of limited irrigation on lettuce and Chinese cabbage yields. Irrig Sci 9, 187-1 98. doi:10.1007/BF00275431.

Stagnari F, Galiene A, Pisante M (2015). Shading and nitrogen management affect quality, safety and yield of greenhouse-grown leaf lettuce. Scientia Horticulturae, 192(31), 70-79

Steduto P, Hsiao T C, Fereres E, Raes D (2012). Crop yield response to water (Vol. 1028). Rome: fao.

Stewart J I, Hagan R M, Pruitt WO (1976). Production Functions and Predicted Irrigation Programs for Principal Crops as Required for Water Resources Planning and Increased Water use Efficiency. Tech. Bureau Recl. No: 14 06-D. 7329, USA, p. 80. gov.tr)

TUik (2016). Türkiye İstatistik Kurumu Verileri (mww.tuik.

Yazgan S, Ayas S, Büyükcangöz H (2006). Örtü Altında Yetiștirilen Baș Salatanın (Lactuca sativa var. Olenka) Sulama Zamanın Planlanması. KSÜ. Fen ve Mühendislik Dergisi. 9 (1): 88-91

Yıldırım M, Bahar E, Demirel K (2015). Farklı Sulama Suyu Seviyelerinin Serada Yetiștirilen KIvırcık Marulun (Lactuca sativa var. campania) Verimi ve Gelișimi Üzerine Etkileri, ÇOMÜ Ziraat Fakültesi Dergisi, 29.

Yurtsever, N (1984). Deneysel İstatistik Metotlar. T.C. Tarım Orman ve Köyișleri Bakanlığı. Köy Hizmetleri Genel Müdürlüğü Yayınları. Genel Yayın No: 121, Teknik Yayın No: 56. Ankara. 